\title{
Atmospheric evolution of emissions from a boreal forest fire: the formation of highly functionalized oxygen-, nitrogen-, and sulfur-containing organic compounds
}

\author{
Jenna C. Ditto ${ }^{1}$, Megan He ${ }^{1}$, Tori N. Hass-Mitchell ${ }^{1}$, Samar G. Moussa ${ }^{2}$, Katherine Hayden ${ }^{2}$, Shao-Meng Li ${ }^{2}$, \\ John Liggio ${ }^{2}$, Amy Leithead ${ }^{2}$, Patrick Lee ${ }^{2}$, Michael J. Wheeler ${ }^{2}$, Jeremy J. B. Wentzell ${ }^{2}$, and Drew R. Gentner ${ }^{1,3}$ \\ ${ }^{1}$ Department of Chemical and Environmental Engineering, Yale University, New Haven, CT 06511, USA \\ ${ }^{2}$ Air Quality Research Division, Environment and Climate Change Canada, Toronto, Ontario M3H 5T4, Canada \\ ${ }^{3}$ Solutions for Energy, Air, Climate and Health (SEARCH), School of the Environment, \\ Yale University, New Haven, CT 06511, USA
}

Correspondence: Drew R. Gentner (drew.gentner@yale.edu)

Received: 20 June 2020 - Discussion started: 6 July 2020

Revised: 27 October 2020 - Accepted: 4 November 2020 - Published: 14 January 2021

\begin{abstract}
Forest fires are major contributors of reactive gasand particle-phase organic compounds to the atmosphere. We used offline high-resolution tandem mass spectrometry to perform a molecular-level speciation of gas- and particlephase compounds sampled via aircraft from an evolving boreal forest fire smoke plume in Saskatchewan, Canada. We observed diverse multifunctional compounds containing oxygen, nitrogen, and sulfur (CHONS), whose structures, formation, and impacts are understudied. The dilutioncorrected absolute ion abundance of particle-phase CHONS compounds increased with plume age by a factor of 6.4 over the first $4 \mathrm{~h}$ of downwind transport, and their relative contribution to the observed functionalized organic aerosol (OA) mixture increased from $19 \%$ to $40 \%$. The dilution-corrected absolute ion abundance of particle-phase compounds with sulfide functional groups increased by a factor of 13 with plume age, and their relative contribution to observed OA increased from $4 \%$ to $40 \%$. Sulfides were present in up to $75 \%$ of CHONS compounds and the increases in sulfides were accompanied by increases in ring-bound nitrogen; both increased together with CHONS prevalence. A complex mixture of intermediate- and semi-volatile gas-phase organic sulfur species was observed in emissions from the fire and depleted downwind, representing potential precursors to particle-phase CHONS compounds. These results demonstrate CHONS formation from nitrogen- and oxygencontaining biomass burning emissions in the presence of re-
\end{abstract}

duced sulfur species. In addition, they highlight chemical pathways that may also be relevant in situations with elevated emissions of nitrogen- and sulfur-containing organic compounds from residential biomass burning and fossil fuel use (e.g., coal), respectively.

\section{Introduction}

Forest fires are predicted to become increasingly prevalent and severe with climate change (Abatzoglou and Williams, 2016; Barbero et al., 2015; Jolly et al., 2015). These fires are an important and uncontrolled source of gas- and particlephase compounds to the atmosphere, including a complex mixture of gas-phase reactive organic carbon, primary organic aerosol (POA), carbon monoxide, carbon dioxide, methane, ammonia, nitrogen oxides, and black carbon (Akagi et al., 2011; Gilman et al., 2015; Hatch et al., 2015, 2018; Koss et al., 2018; Vicente et al., 2013; Yokelson et al., 2013). Many of these emitted compounds are precursors to downwind ozone and secondary organic aerosol (SOA) production (Ahern et al., 2019; Buysse et al., 2019; Gilman et al., 2015; Hennigan et al., 2011; Lim et al., 2019).

Primary and secondary pollutants from biomass burning have important effects on air quality locally, regionally, and continentally (Burgos et al., 2018; Colarco et al., 2004; Cottle et al., 2014; Dreessen et al., 2016; Forster et al., 2001; 
Rogers et al., 2020; Val Martín et al., 2006), and their impacts on human health and climate (e.g., via light-absorbing brown and black carbon) have been well documented (Forrister et al., 2015; Jiang et al., 2019; Liu et al., 2017; Di Lorenzo et al., 2018; Reid et al., 2016; Sengupta et al., 2018; Wong et al., 2019). These health and climate effects are sensitive to the elemental and structural composition of gas- and particle-phase emissions and transformation products (Hallquist et al., 2009; Nozière et al., 2015). As a result, past studies have used online and offline mass spectrometry techniques to characterize the chemical composition of fresh and aged biomass burning emissions and have revealed a wide array of emitted hydrocarbons and oxygen-, nitrogen-, or sulfur-containing functionalized species (Ahern et al., 2019; Bertrand et al., 2018; Gilman et al., 2015; Hatch et al., 2015, 2018, 2019; Iinuma et al., 2010; Koss et al., 2018; Laskin et al., 2009; Yokelson et al., 2013). However, the emissions and chemical transformations occurring in ambient biomass burning plumes are extremely complex and despite previous measurements remain poorly understood at the molecular level.

In this study, we used an aircraft sampling system developed to collect offline gas- and particle-phase organic compounds above a boreal forest fire. We examined the molecular-level emissions and evolution of the forest fire plume via an analysis of these offline samples using gas and liquid chromatography (GC/LC) with high-resolution mass spectrometry (MS), including tandem mass spectrometry (MS/MS). This degree of detailed chemical speciation is important to advance knowledge of in-plume chemical pathways and reaction products, long-distance transport, and fate of biomass burning products - all of which will improve modeling capabilities and our understanding of the health and environmental impacts of biomass burning.

Specifically, the goals of this study were (1) to perform a detailed speciation of gas- and particle-phase organic compounds derived from the boreal forest fire in terms of elemental and functional group composition, to assess changes in composition at the molecular level as the plume aged and (2) to examine the evolution of oxygen-, nitrogen-, and sulfur-containing (CHONS) compounds. These CHONS compounds made up $19 \%-40 \%$ of functionalized OA here and have been observed at other ambient sites (e.g., 9\%$11 \%$; Ditto et al., 2018), though little is known about their structures or formation mechanisms. Using our observations of gas-phase sulfur species, we identified possible precursors and reaction pathways involved in the formation of these CHONS compounds.

\section{Materials and methods}

On 25 June 2018, two research flights were conducted by Environment and Climate Change Canada as part of their Air Pollution research program. These flights sampled two boreal wildfire smoke plumes originating near Lac La Loche in northern Saskatchewan, Canada (Fig. S1). The region is dominated by pine and spruce trees (Canada's National Forest Inventory, 2020). Gas- and particle-phase samples were collected from the National Research Council of Canada's Convair 580 research aircraft for analysis with offline high-resolution mass spectrometry, alongside many other measurements (Sects. S1-S2). The aircraft flew the same straight-line tracks at multiple altitudes through the smoke plumes (average altitudes shown in Table S1), which when stacked created a virtual screen intercepting the plumes at each of five downwind locations (with flight design similar to those previously reported (Li et al., 2017; Liggio et al., 2016)). Screen 1 was $\sim 10 \mathrm{~km}$ from the fire with screens 2 4 following the plumes downwind and screen 5 intercepting the plumes after they had passed over several major surface and in situ mining oil sands facilities (Fig. S1). The samples discussed here were collected across both plumes to ensure that enough mass was present to well surpass the mass spectrometer's detection limits. Based on satellite information and aircraft measurements at the start of sampling (i.e., screen 1), the fire was a low-intensity surface fire with smoldering conditions; aircraft measurements indicated a modified combustion efficiency of $0.90 \pm 0.01$ for both plumes.

Combined gas- and particle-phase samples were collected onto custom adsorbent tubes packed with high-purity quartz wool, glass beads, Tenax TA, and Carbopack X (Sheu et al., 2018). Samples were collected along screens 1-4 in Fig. S1 (no adsorbent tubes collected at screen 5) via an external pod mounted under the wing of the aircraft, which included remote switching between adsorbent tubes at various transect altitudes and online measurements of temperature, pressure, and flow (Sect. S1, Fig. S2).

All adsorbent tubes were analyzed using a Gerstel Thermal Desorber TD 3.5+ with gas chromatography (Agilent 7890B $\mathrm{GC}$ ), atmospheric pressure chemical ionization (APCI), and quadrupole time-of-flight mass spectrometry (Agilent 6550 Q-TOF), similar to past work (Khare et al., 2019). For adsorbent tubes, the APCI was operated in positive ionization mode and the Q-TOF was operated in MS mode (i.e., TOF data collection only, hereafter "GC-APCI-MS"). Adsorbent tube data were processed primarily via a targeted approach for $\mathrm{C}_{x} \mathrm{H}_{y}, \mathrm{C}_{x} \mathrm{H}_{y} \mathrm{O}_{1}, \mathrm{C}_{x} \mathrm{H}_{y} \mathrm{~S}_{1}$, and $\mathrm{C}_{x} \mathrm{H}_{y} \mathrm{~N}_{1}$ compounds using custom Igor Pro code (Sects. S2-S3).

In order to reduce losses of lower-volatility gases onto upstream surfaces, particles were not explicitly filtered out at the inlet of the wing-pod sampler used for adsorbent tube collection. For several reasons, it was concluded that the $\mathrm{C}_{x} \mathrm{H}_{y}$ hydrocarbons smaller than $\mathrm{C}_{22-23}$ (and $\mathrm{C}_{x} \mathrm{H}_{y} \mathrm{~S}_{1}, \mathrm{C}_{x} \mathrm{H}_{y} \mathrm{O}_{1}$, and $\mathrm{C}_{x} \mathrm{H}_{y} \mathrm{~N}_{1}$ compounds of similar volatility) measured in the adsorbent tubes were predominantly in the gas phase. This was based on (1) significant undersampling for particles at the wing pod inlet since the adsorbent tube sampling flow rate was a factor of $\sim 4$ lower than its corresponding isokinetic flow rate, resulting in a significant divergence of 
particles away from the inlet during sampling, and (2) partitioning theory, using average in-plume organic aerosol (OA) concentrations of $18-22 \mu \mathrm{g} / \mathrm{m}^{3}$ across adsorbent tube sampling periods for screens $1-4$, concurrently measured by an aerosol mass spectrometer (AMS) on board the aircraft (see Sects. S1, S3, Table S2). Thus, the $\mathrm{C}_{22}$ and smaller $\mathrm{C}_{x} \mathrm{H}_{y}$ compounds (and other compound classes of similar volatility) should have primarily been in the gas phase at equilibrium. As such, we limited the following adsorbent tube data analysis to compounds in the $\mathrm{C}_{10}-\mathrm{C}_{25}$ range to focus on intermediate-volatility and semivolatile compounds (I/SVOCs) present in the gas phase. In our analyses and interpretation, the compounds included in each of these volatility ranges are defined based on fixed values of saturation mass concentrations (e.g., Donahue et al., 2011; Murphy et al., 2014 ) at the observed $18-22 \mu \mathrm{g} / \mathrm{m}^{3}$ OA loadings present during adsorbent tube sampling times.

Dedicated particle-phase samples were collected on $47 \mathrm{~mm}$ PTFE filters $(2.0 \mu \mathrm{m}$ pore; Pall Corporation) from a sampling manifold in the aircraft cabin containing six independent anodized aluminum filter holders. The filters were sampled behind an isokinetic inlet with a size cutoff of approximately $2.5 \mu \mathrm{m}$. One filter sample was collected per screen for screens 1-5 shown in Fig. S1.

Filter samples were extracted in methanol (Ditto et al., 2018). Samples were analyzed via liquid chromatography (Agilent 1260 LC) with electrospray ionization (ESI) and the same Q-TOF. For filters, the ESI source was operated in both positive and negative ionization modes, and the QTOF was operated in both MS mode (i.e., TOF data collection, "LC-ESI-MS") and MS/MS mode (i.e., tandem mass spectral data collection, "LC-ESI-MS/MS") (Ditto et al., 2018, 2020). Filter extracts were also analyzed using GCAPCI-MS in positive ionization mode. Filter data from LCESI-MS, LC-ESI-MS/MS, and GC-APCI-MS were analyzed with a non-targeted approach, using Agilent Mass Hunter, SIRIUS with CSI:FingerID and custom R code (Sects. S2S3) (Ditto et al., 2018, 2020). All peaks that passed strict QA/QC (Sect. S3) were assigned molecular formulas, with candidate formulas limited to 20 oxygen, 3 nitrogen, and/or 1 sulfur atom(s). Hereafter, LC-ESI compound classes are discussed here without subscripts.

The particle-phase compounds observed via LC-ESI vs. GC-APCI techniques varied significantly in their oxygen, nitrogen, and sulfur content since these two chromatographic and ionization approaches are sensitive towards different types of compounds (see Sect. S5). As the forest fire plume aged, the complex mixture of emissions and secondary products became increasingly functionalized and thus less GCamenable without derivatization. Therefore, we focused on LC-ESI-MS data to study these functionalized particle-phase compounds. We acknowledge that this method excludes fully reduced hydrocarbons and fully reduced sulfur-containing particle-phase compounds (i.e., $\mathrm{CH}$ and CHS; Ditto et al.,
2018) and thus these compound classes are not accounted for in the relative particle-phase distributions shown here.

For particle-phase analyses, we estimated saturation mass concentration based on the $\mathrm{Li}$ et al. parameterization ( $\mathrm{Li}$ et al., 2016) and then grouped compounds based on fixed volatility bins (Donahue et al., 2011; Murphy et al., 2014). Particle-phase compounds were observed across the intermediate-volatility organic compound (IVOC), semivolatile organic compound (SVOC), low-volatility organic compound (LVOC), and extremely low-volatility organic compound (ELVOC) ranges. Particle-phase IVOCs have been observed in the past and despite their higher volatility may exist in the particle phase due to their polarity and water solubility. Additional details on these methods, including a discussion of total mass analyzed from filters/adsorbent tubes and QA/QC, are discussed in Sects. S1S. A method summary is shown in Fig. S3.

\section{Results}

\subsection{Evolution of organic aerosol elemental composition and functionality with plume age}

Our analysis of functionalized OA showed several compositional trends in the evolving boreal forest fire smoke plume (screens 1-4) and exhibited marked changes after emissions from the oil sands facilities were mixed with the forest fire plume (screen 5). Here, we focused on the forest fire plume in screens $1-4$. We observed a diverse elemental composition in functionalized OA across oxygen-, nitrogen-, and/or sulfurcontaining compound classes (Figs. 1a-b, S5). This included oxygenates $(\mathrm{CHO})$, such as common biomass burning tracers and their isomers (e.g., levoglucosan, Sect. S2); as well as oxygen- and nitrogen-containing (CHON) compounds; oxygen- and sulfur-containing (CHOS) compounds; reduced nitrogen-containing (CHN) compounds; reduced nitrogenand sulfur-containing (CHNS) compounds; and compounds containing oxygen, nitrogen, and sulfur (CHONS).

There was a continual decrease in the relative abundance of particle-phase $\mathrm{CHO}$ compounds in the observed functionalized OA across screens $1-4$, accompanied by a consistent relative increase in CHON and CHONS compounds (Fig. 1b). Notably, the relative abundance of CHONS compounds increased from $19 \%$ to $40 \%$ of measured functionalized OA from screens 1 to 4 . Trends in absolute ion abundances were also similar (note: carbon monoxide mixing ratio was used to account for dilution). This is shown in Fig. 1c (inset) and Fig. S5c; CHO generally decreased from screens 1 to 4, while CHONS and CHON generally increased, suggesting that CHONS compounds were possibly formed from $\mathrm{CHO}, \mathrm{CHN}$, and/or CHON precursors in the gas and/or particle phases. Specifically, the dilution-corrected abundance of CHONS species increased by a factor of 6.4 from screens 1 to 4 (Fig. 1c, inset). In Fig. 1, we primarily presented data as rel- 
(a) Functionalized OA compound classes

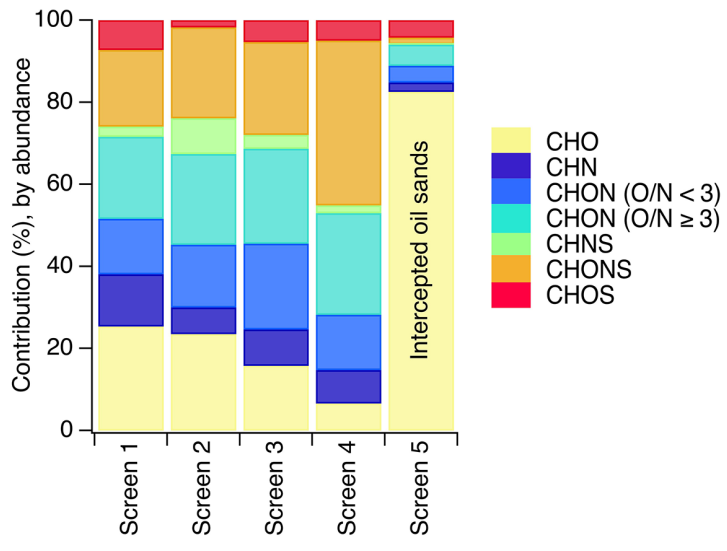

(c) OA functional group distribution

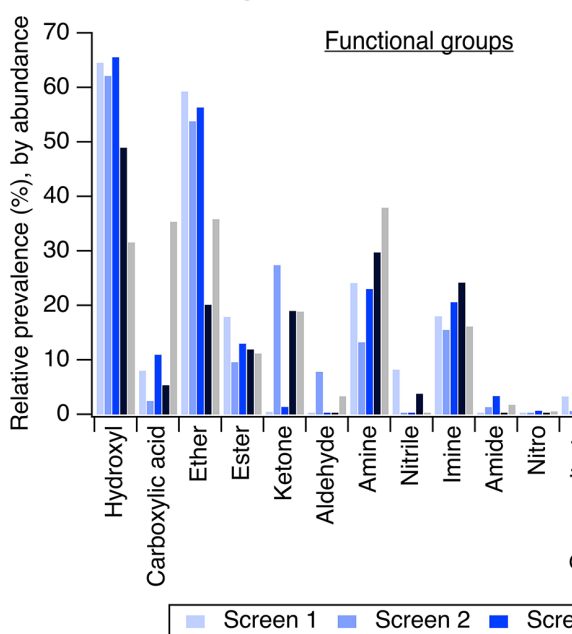

(b) Functionalized OA time series

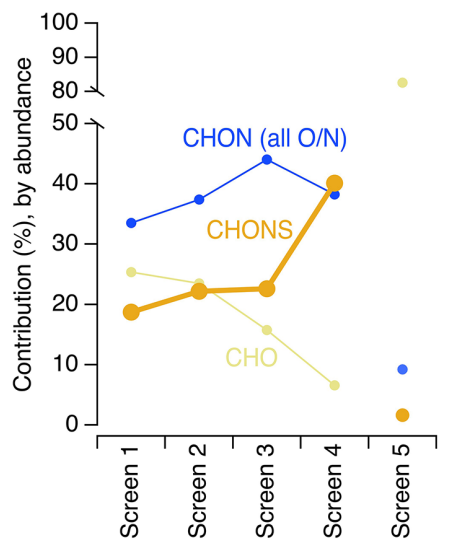
percent contribution of each compound class to the total compound abundance measured by LC-ESI-MS. (b) Percent contribution of CHO, CHON, and CHONS compound classes in functionalized OA as a function of plume age. CHON compounds in (b) are summed across all $\mathrm{O} / \mathrm{N}$ ratios. (c) Functional groups and structural features present in measured functionalized OA (from non-targeted LC-ESI-MS/MS). The sulfide functional group is shown here for emphasis and will be the subject of subsequent analyses. The inset in (c) shows the absolute CHONS ion abundance normalized by $\mathrm{CO}$ mass (orange trace, left $y$ axis) and the absolute sulfide ion abundance normalized by CO mass (black trace, right $y$ axis). Full CO-adjusted compound class and functional group abundance data are shown in Figs. S5-S6. For panels $(\mathbf{a}-\mathbf{c})$, results tabulated by occurrence are also shown in Figs. S5-S6.

ative contributions to functionalized OA to examine changes in the evolution of the complex mixture as a whole and the relationships between different compound classes and functional groups with plume age. However, dilution-corrected abundances are also important for understanding absolute formation (or depletion) and are shown for all species in Figs. S5-S6.

Based on MS/MS analyses, these evolving $\mathrm{CHO}, \mathrm{CHN}$, $\mathrm{CHON}$, and CHONS compounds were often comprised of variable combinations of hydroxyl and ether functional groups (e.g., primary emissions from forest fires like methoxyphenols and similar structures), as well as amine, imine, and sulfide groups, along with cyclic nitrogen struc- tural features (consistent with past laboratory observations of biomass burning emissions; Laskin et al., 2009; Lin et al., 2018; Liu et al., 2015; Updyke et al., 2012).

\subsection{Detailed speciation of CHONS compounds in functionalized $\mathrm{OA}$}

While some individual CHONS species contained grouped oxygen, nitrogen, and sulfur atom moieties (e.g., sulfonamides), the majority of CHONS compounds had a combination of multiple separate oxygen-, nitrogen-, and/or sulfurcontaining functional groups (Fig. 2a-b). Sulfide groups were important contributors to CHONS compounds (Fig. 2b) 
and showed a notable increase in relative contribution to the overall functional group distribution with plume age (Fig. 1c). They increased from $4 \%$ to $40 \%$ of measured compound abundance across screens 1 to 4 (Fig. 1c), which corresponded to an increase by a factor of 13 in terms of their dilution-corrected abundance (Fig. 1c, inset). Their increasing relative contribution to CHONS compounds with plume evolution was even more pronounced - by screen 4 , the sulfide functional group was present in $75 \%$ of detected CHONS compound abundance (Fig. S7a). Here, we focused on the presence of sulfides in CHONS compounds because most of the observed particle-phase sulfides occurred as part of CHONS species (71\%), while a smaller fraction occurred in CHOS $(21 \%)$ or CHNS (8\%) compounds (Fig. 3a).

To explore possible precursors and formation pathways for these particle-phase sulfide-containing CHONS species, we used MS/MS to identify nitrogen-containing functional groups that co-occurred with sulfides. In CHONS compounds, most sulfides co-occurred with cyclic nitrogen ( $36 \%$ of sulfide-containing species), amine (32\%), or imine features $(43 \%)$ (Fig. 3b). The prevalence of sulfide and cyclic nitrogen features in the measured functionalized OA increased together screen to screen and increased together with the rising proportion of CHONS compounds (Fig. 3c). While sulfides often co-occurred with amines or imines and while amines and imines were prevalent in all four screens (Fig. 1c), there was no relationship between these functional groups and the increasing contribution of CHONS compounds to measured functionalized OA (Fig. S7b).

The sulfide substructures observed via MS/MS often contained linear carbon chains or phenyl groups bonded to the sulfur atom (Fig. $3 \mathrm{c}$ inset). Thus, we hypothesize that precursors with similar reduced sulfur-containing structures reacted with cyclic nitrogen-containing species to form the observed particle-phase sulfide-containing CHONS compounds (see further discussion of possible precursors in Sect. 3.3 and potential chemical pathways in Sect. 4.2).

CHONS compounds were predominantly SVOCs in screens 1-4 (i.e., $89 \%$ of CHONS ion abundance, Figs. 2c, S8), suggesting that these compounds were formed from higher-volatility gas-phase species. In contrast, with the added influence of the oil sands facilities in screen 5, $68 \%$ of CHONS compounds were extremely low-volatility organic compounds (ELVOCs), though CHONS made up only $2 \%$ of functionalized OA at screen 5 .

Overall, dilution-corrected abundances of functionalized $\mathrm{OA}$ in each particle-phase volatility bin increased with plume age, but the relative contribution of SVOCs increased from $37 \%$ to $58 \%$ while the relative contribution of IVOCs dropped from $38 \%$ to $20 \%$, potentially due to oxidation reactions that formed SVOCs and/or due to evaporation (Fig. S9). These particle-phase IVOCs consisted predominantly of $\mathrm{CHO}, \mathrm{CHN}$, and $\mathrm{CHON}(\mathrm{O} / \mathrm{N}<3)$ compounds, which could include possible non-sulfur-containing precursors to the observed CHONS species. Fragmentation of (a) N-containing contribution to CHONS OA

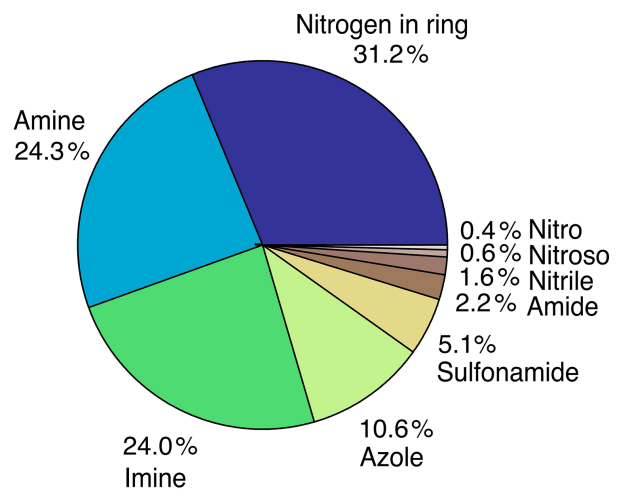

(b) S-containing contribution to CHONS OA

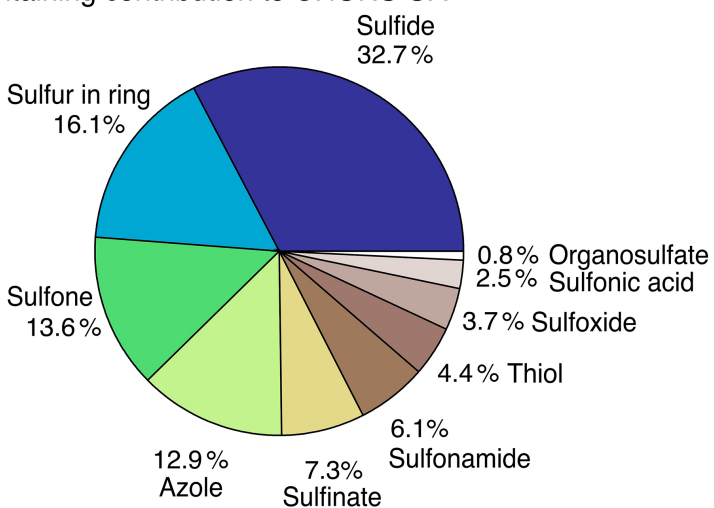

(c) CHONS volatility distribution in functionalized $\mathrm{OA}$

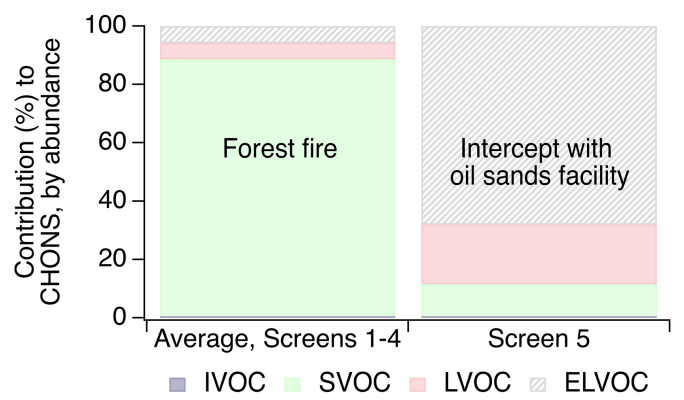

Figure 2. (a) The distribution of nitrogen-containing functional groups to particle-phase CHONS compounds (organonitrates are excluded here due to challenges with their identification using SIRIUS with CSI:FingerID, but contributed minimally to CHONS, Sect. S3). (b) The distribution of sulfur-containing groups to particle-phase CHONS compounds. For panels (a-b), data are averaged across screens 1-4, with individual screens shown in Fig. S7a. (c) Volatility distribution of particle-phase CHONS species. These volatility data were averaged across screens $1-4$, and individual screens are shown in Fig. S8. Volatility was estimated with the parameterization in Li et al. (2016) and grouped according to volatility bins in Donahue et al. (2011).

particle-phase L/ELVOC compounds also could have contributed to some of the observed SVOC mass, but the overall increasing total abundance across all volatility bins with plume age supports the idea that these compounds 
(a) Compound class of sulfides in functionalized $O A$

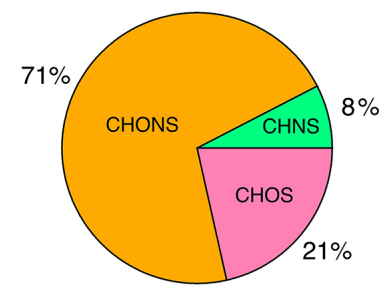

(b) N-groups co-occurring with sulfides in functionalized $O A$

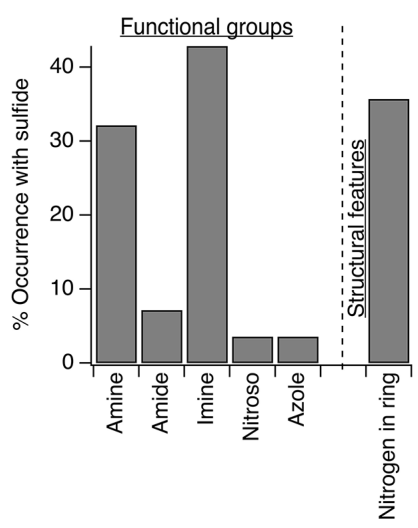

(c) Evolution with CHONS OA

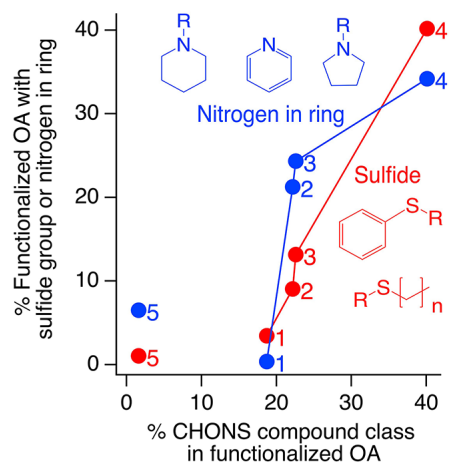

Figure 3. (a) Compound class distribution of sulfide groups: $71 \%$ of sulfide functional groups observed (weighted by ion abundance) were present in CHONS compounds. (b) Co-occurrence of sulfides and nitrogen-containing groups. Data shown in (a-b) are cumulative across compounds in screens 1-4. (c) The relative contribution of sulfides and cyclic nitrogen groups to all functionalized OA increased together with the increasing contribution of CHONS compounds. The other functional groups in (b) showed no relationship with the increase in CHONS (Fig. S7b). Structures represent examples of commonly observed sulfide and cyclic nitrogen substructures from SIRIUS and CSI:FingerID (Sect. S3), where ring structures associated with nitrogen heteroatoms were free standing, adjacent to other rings, and/or contained additional attached functional groups.

were predominantly formed from more volatile precursors (e.g., I/SVOCs).

\subsection{Targeted search for CHONS precursors in the gas phase}

To investigate the precursors and chemistry that could have formed the sulfide-containing CHONS species observed in the particle-phase samples, we performed a targeted search for possible gas-phase I/SVOC species in each adsorbent tube, across all $\mathrm{C}_{10}-\mathrm{C}_{25} \mathrm{C}_{x} \mathrm{H}_{y} \mathrm{~S}_{1}$ species with the equivalent of 0-15 double bonds and/or rings (i.e., $\mathrm{C}_{x} \mathrm{H}_{2 x+2} \mathrm{~S}_{1}-$ $\mathrm{C}_{x} \mathrm{H}_{2 x-28} \mathrm{~S}_{1}$, Figs. 4a, S10). We observed a distribution of $\mathrm{C}_{x} \mathrm{H}_{y} \mathrm{~S}_{1}$ compounds and their isomers; based on the highmass-resolution and high-mass-accuracy molecular formulas from targeted GC-APCI-MS analysis, $27 \%$ of $\mathrm{C}_{x} \mathrm{H}_{y} \mathrm{~S}_{1}$ compounds were fully saturated (i.e., $\mathrm{C}_{x} \mathrm{H}_{2 x+2} \mathrm{~S}_{1}$ ) and $25 \%$ contained the equivalent of four to six double bonds and/or rings (i.e., $\mathrm{C}_{x} \mathrm{H}_{2 x-6} \mathrm{~S}_{1}-\mathrm{C}_{x} \mathrm{H}_{2 x-10} \mathrm{~S}_{1}$ ), which included single-ring aromatics. We focused on these sulfur-containing gases as candidate precursors to the observed particle-phase sulfidecontaining CHONS compounds as they contained sulfur substructures with linear carbon chains or phenyl groups, similar to those observed on particle-phase CHONS compounds via MS/MS analysis (Figs. 3c inset, S10-S11). However, we also observed contributions from other sulfur-containing structures (e.g., with the equivalent of one to three double bonds and/or rings, Fig. 4a), which could also have been precursor species.

The observed gas-phase $\mathrm{C}_{10}-\mathrm{C}_{25} \quad \mathrm{C}_{x} \mathrm{H}_{y} \mathrm{~S}_{1}$ compounds were present in gas-phase emissions from the fire and likely also evaporated from primary OA during early plume dilution. Gas-phase $\mathrm{C}_{10}-\mathrm{C}_{25} \mathrm{C}_{x} \mathrm{H}_{y} \mathrm{~S}_{1}$ concentrations increased relative to carbon monoxide from screens 1 to 2 and then steadily decreased with plume age (Figs. 4b, S12a). This suggests the gas-phase emission and/or evaporation of $\mathrm{C}_{x} \mathrm{H}_{y} \mathrm{~S}_{1}$ compounds from OA between screens 1 and 2, and subsequent participation in plume chemistry from screens 2 to 4 .

Similar OA evaporation with plume dilution has been observed in many past studies (Ahern et al., 2019; Garofalo et al., 2019; Hennigan et al., 2011; Lim et al., 2019). To better understand the dynamics of these sulfur-containing compounds and their possible particle-phase origin, we compared their concentrations to those of $\mathrm{C}_{10}-\mathrm{C}_{25}$ aliphatic and aromatic $\mathrm{C}_{x} \mathrm{H}_{y}$ and $\mathrm{C}_{x} \mathrm{H}_{y} \mathrm{O}_{1}$ species from a similar targeted search of adsorbent tube gas-phase compounds. Overall, $\mathrm{C}_{x} \mathrm{H}_{y}$ and $\mathrm{C}_{x} \mathrm{H}_{y} \mathrm{O}_{1}$ compound classes dominated the observed $\mathrm{C}_{10}-\mathrm{C}_{25}$ compounds (Figs. $4 \mathrm{~b}, \mathrm{~S} 12 \mathrm{~b}$ ), with $61 \%$ $\mathrm{C}_{x} \mathrm{H}_{y}, 36 \% \mathrm{C}_{x} \mathrm{H}_{y} \mathrm{O}_{1}$, and just $3 \% \mathrm{C}_{x} \mathrm{H}_{y} \mathrm{~S}_{1}$ on average. $\mathrm{C}_{x} \mathrm{H}_{y}$ and $\mathrm{C}_{x} \mathrm{H}_{y} \mathrm{O}_{1}$ concentrations generally increased with plume age (Fig. 4b) and included many known compound types (e.g., monoterpenes, aromatics, hydroxyls, carbonyls; Akagi et al., 2011; Andreae, 2019; Gilman et al., 2015; Hatch et al., 2015, 2019; Koss et al., 2018). This suggests the direct emission of these gas-phase compound classes from the fire (observed at screen 1) along with the evaporation of semivolatile particle-phase emissions as the plume evolved, and formation of $\mathrm{C}_{x} \mathrm{H}_{y} \mathrm{O}_{1}$ via $\mathrm{C}_{x} \mathrm{H}_{y}$ oxidation. AMS measurements of total $\mathrm{OA}$ concentrations provided supporting evidence of OA evaporation; the ratio of AMS OA concentration to CO decreased by $7 \%$ from screens 1 to 2 (corresponding to an AMS OA/CO ratio of -0.0044 or a decrease 
(a) Average gas-phase $\mathrm{C}_{x} \mathrm{H}_{y} \mathrm{~S}_{1}$ distribution

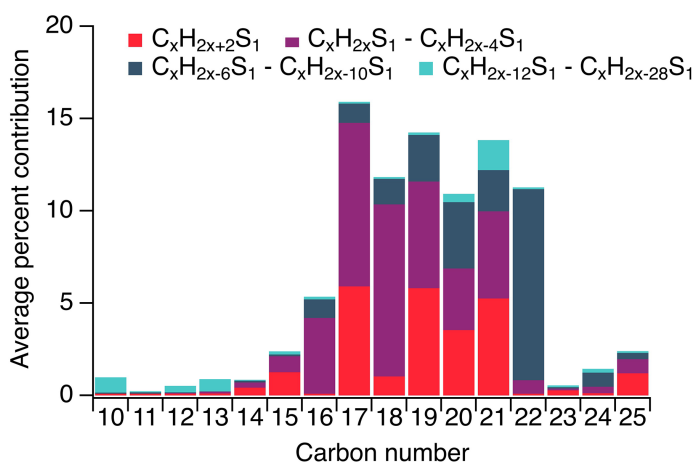

(b) Gas-phase and AMS OA concentrations normalized by $\mathrm{CO}$

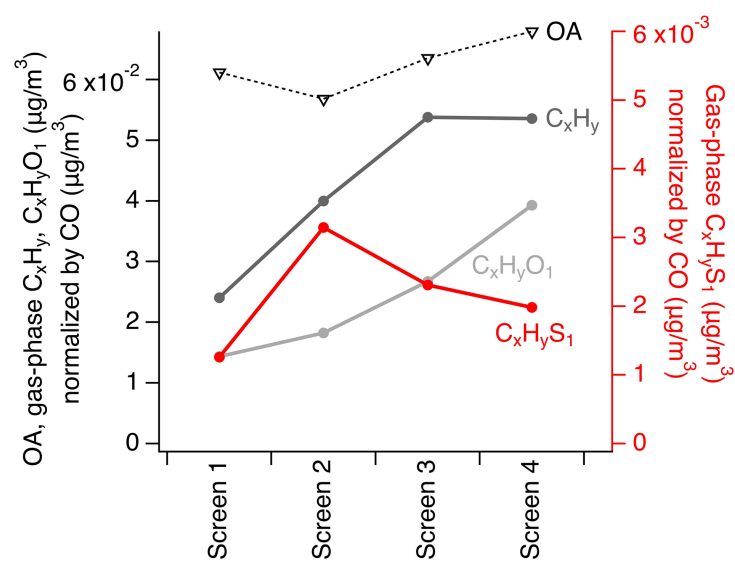

Figure 4. (a) The average $\mathrm{C}_{x} \mathrm{H}_{y} \mathrm{~S}_{1}$ distribution from targeted GCAPCI-MS across all gas-phase adsorbent tube samples from screens 1-4 (see Fig. S10 for individual $\mathrm{C}_{x} \mathrm{H}_{y} \mathrm{~S}_{1}$ screens and Fig. S13 for $\mathrm{C}_{x} \mathrm{H}_{y}$ ). (b) Concentrations of gas-phase $\mathrm{C}_{x} \mathrm{H}_{y}, \mathrm{C}_{x} \mathrm{H}_{y} \mathrm{O}_{1}$, and $\mathrm{C}_{x} \mathrm{H}_{y} \mathrm{~S}_{1}$ from targeted GC-APCI-MS analysis of adsorbent tubes, shown with total OA from AMS, all corrected for dilution using carbon monoxide measurements (see Fig. S12a for non-normalized concentrations). Data in (b) are averaged over low- and highaltitude adsorbent tube samples.

in OA concentrations of $-2.3 \mu \mathrm{g} / \mathrm{m}^{3}$ ), while the ratio of total gas-phase $\mathrm{C}_{x} \mathrm{H}_{y}, \mathrm{C}_{x} \mathrm{H}_{y} \mathrm{O}_{1}$, and $\mathrm{C}_{x} \mathrm{H}_{y} \mathrm{~S}_{1}$ concentration to $\mathrm{CO}$ increased by $55 \%$ (corresponding to a total gas-phase concentration/CO ratio of 0.022 or an increase in gas-phase concentration of $7.0 \mu \mathrm{g} / \mathrm{m}^{3}$, with changes summarized in Table S3). While not the focus of the analytical approaches applied in this study, to further substantiate the observation of OA evaporation, we performed the same targeted analysis of $\mathrm{C}_{10}-\mathrm{C}_{25} \mathrm{C}_{x} \mathrm{H}_{y}, \mathrm{C}_{x} \mathrm{H}_{y} \mathrm{O}_{1}$, and $\mathrm{C}_{x} \mathrm{H}_{y} \mathrm{~S}_{1}$ compounds in the particle-phase filter sample extracts analyzed via GC-APCIMS. We observed a similar decrease in concentration from screens 1 to 2. However, these filter measurements (even with APCI ionization) were not geared towards $\mathrm{C}_{x} \mathrm{H}_{y}$ and $\mathrm{C}_{x} \mathrm{H}_{y} \mathrm{~S}_{1}$ speciation due to possible solubility limitations in the extraction solvent (Sect. S4). Direct thermal desorption of quartz filters with GC-APCI analysis would be better suited for these $\mathrm{C}_{x} \mathrm{H}_{y}$ and $\mathrm{C}_{x} \mathrm{H}_{y} \mathrm{~S}_{1}$ measurements (as performed in this study with adsorbent tubes).

As discussed in the Materials and methods section, the observed compounds with volatilities below that of $\sim \mathrm{C}_{22}-\mathrm{C}_{23}$ hydrocarbons existed primarily in the gas phase (Table S2), while larger compounds favored the particle phase (with a smaller fraction in the gas phase at equilibrium). The presence of gas-phase compounds across this I/SVOC range (e.g., Figs. S10, S13) further corroborates the possibility of contributions from both direct gas-phase emissions and from evaporation of particle-phase emissions (Sect. S3). In contrast to $\mathrm{C}_{x} \mathrm{H}_{y}$ concentrations, $\mathrm{C}_{x} \mathrm{H}_{y} \mathrm{~S}_{1}$ concentrations dropped markedly after screen 2 despite similarities in the volatility distribution of $\mathrm{C}_{x} \mathrm{H}_{y}$ and $\mathrm{C}_{x} \mathrm{H}_{y} \mathrm{~S}_{1}$ I/SVOC mixtures (Figs. 4a, $\mathrm{S} 10$ and $\mathrm{S} 13$ ). This difference across screens shows that the observed $\mathrm{C}_{x} \mathrm{H}_{y} \mathrm{~S}_{1} \mathrm{I} / \mathrm{SVOCs}$ were removed (e.g., via chemical reactions) more quickly than $\mathrm{C}_{x} \mathrm{H}_{y}$ (Fig. 4b), thus supporting their potential contribution to CHONS formation.

In addition to the $\mathrm{C}_{10}-\mathrm{C}_{25} \quad \mathrm{C}_{x} \mathrm{H}_{y} \mathrm{~S}_{1}$ compounds measured in the adsorbent tubes, smaller sulfur-containing compounds could have also acted as CHONS precursors, like those identified by the onboard proton-transfer-reaction mass spectrometer (PTR-ToF-MS). While dimethyl sulfide (DMS, previously observed in biomass burning smoke (Andreae, 2019)) was often below the instrument's limit of detection, both dimethyl and diethyl sulfide showed good correlation with acetonitrile (a well-known biomass burning product; Andreae, 2019) in the smoke plume during screen $1(r \sim$ 0.95 , Fig. S12c). This suggests that these compounds were co-emitted by the fire.

\section{Discussion}

\subsection{Investigating possible origins of gas-phase sulfur compounds}

The gas-phase sulfur-containing compounds observed in the plume were emitted from the smoldering fire. However, their origins are uncertain, since the broader range of sulfur species found here (Figs. 4a, S10-S11) has not been previously reported; many of the compounds in the complex mixture of sulfur-containing compounds discussed in this work were outside the detection range of previously employed methods (Hatch et al., 2015; Khare et al., 2019; Koss et al., 2018; Sekimoto et al., 2018). Here, we explore two potential origins of these gas-phase sulfur-containing precursors to the observed particle-phase CHONS compounds: the biomass fuel itself and the deposition of sulfur species from anthropogenic/industrial operations.

Fuel. In past studies, emissions of sulfur-containing organic compounds were typically minor compared to oxygenor nitrogen-containing compounds, and the relative balance of oxygen-, nitrogen-, or sulfur-containing compound emissions was typically proportional to fuel content (Hatch et al., 
2015; Ward, 1990). The estimated N : S ratio for boreal forest fuel near the fire was $\sim 10: 1$ (Huang and Schoenau, 1996), which was similar to the average $\mathrm{N}: \mathrm{S}$ ratio from a non-targeted search for nitrogen- and sulfur-containing I/SVOCs from the adsorbent tube samples in this study of $(8.1 \pm 4.8): 1$. Sulfur is an essential nutrient in plants and can be taken up from soil (as sulfate) or from the atmosphere via deposition (as $\mathrm{SO}_{2}$ and sulfate) (Aas et al., 2019; Gahan and Schmalenberger, 2014; Leustek, 2002). Both $\mathrm{SO}_{2}$ and sulfate are metabolized in plants to yield a variety of compounds critical to plant functions including cysteine and a range of other sulfur-containing (as well as oxygen- and nitrogencontaining) compounds (Leustek, 2002). In addition, disulfide bonds contribute to plant protein structure, and these bonds can cleave and form thiols (Gahan and Schmalenberger, 2014; Leustek, 2002; Onda, 2013). Sulfur-containing compounds like these may have been emitted during the fire, along with other known sulfur products from boreal fuels (e.g., DMS, thiophenes; Akagi et al., 2011; Hatch et al., 2015; Koss et al., 2018; Landis et al., 2018).

Deposition. While sulfur can be naturally occurring, it is also associated with anthropogenic activities (e.g., transportation, power generation, industry). A portion of the sulfur in the forest fire emissions could have originated from sulfur deposited via such anthropogenic activities. The closest large anthropogenic sulfur source to the fire location was the oil sands mining region north of Fort McMurray, Alberta, which was approximately $150 \mathrm{~km}$ away and which contains known $\mathrm{SO}_{2}$ emitters (Liggio et al., 2017; McLinden et al., 2016). Regional concentrations of $\mathrm{SO}_{2}$ or other sulfur species from these nearby industrial activities could have led to accumulated deposition of inorganic and/or organic sulfur compounds over time, though it is uncertain how much of this deposited sulfur would have been taken up and transformed by vegetation due to sulfur uptake and assimilation regulatory pathways in plants (Davidian and Kopriva, 2010). This possible accumulated deposition may have acted as a reservoir of sulfur to be emitted during fires via the re-volatilization of deposited compounds, in addition to the evaporation of typical sulfur metabolites or the formation of sulfur-containing combustion by-products. This hypothesis is consistent with recent deposition measurement and modeling results for the region, which indicated that sulfur deposition from the oil sands operations potentially impacted areas downwind, including the region where this fire occurred (Makar et al., 2018).

Interestingly, lichen and spruce trees, which are prominent in the region of the fire discussed here, have been reported to accumulate sulfur from $\mathrm{SO}_{2}$ in regions near large industrial $\mathrm{SO}_{2}$ sources (Meng et al., 1995; Nyborg et al., 1991). Also, past studies have reported enhancements in sulfate (as well as nitrate/ammonium) aerosols coming from biomass burning in areas with urban influence (Fenn et al., 2015; Hecobian et al., 2011; Hegg et al., 1987). Inorganic aerosol components from both urban (e.g., Edmonton, Alberta) and industrial (e.g., oil sands) sources could deposit in the area surrounding the emissions source along with an organic phase, which we postulate could contain a range of sulfur-containing species including the $\mathrm{C}_{x} \mathrm{H}_{y} \mathrm{~S}_{1}$ compounds shown here. These deposited inorganic and organic species may have re-volatilized during the fire. However, further work is needed to disentangle the contribution of natural vs. anthropogenic sulfur to biomass burning emissions in the region. Also, we note that the fire was $\sim 1 \mathrm{~h}$ old at the time of sampling, so the recent application of fire suppressants was unlikely to contribute to the species observed.

\subsection{Potential reaction pathways leading to sulfides in CHONS from sulfur precursors}

A number of potential reactions involving sulfur-containing precursors, often thiols ( $\mathrm{R}-\mathrm{SH})$, may have contributed to the formation of the observed sulfide functional groups in particle-phase CHONS compounds (Fig. S14). On average, our gas-phase measurements were comprised of $27 \%$ fully saturated sulfur-containing hydrocarbons (i.e., $\mathrm{C}_{x} \mathrm{H}_{2 x+2} \mathrm{~S}_{1}$, Figs. S10-S11). It is likely that some fraction of the sulfur compounds observed in the gas-phase adsorbent tube measurements (e.g., the compounds identified as $\mathrm{C}_{x} \mathrm{H}_{2 x+2} \mathrm{~S}_{1}$ ) and in PTR-ToF-MS measurements (e.g., dimethyl sulfide, diethyl sulfide) were thiols, but the distinction between sulfide vs. thiol isomers was challenging with these methods without specific internal standards.

In some of the following possible reactions, a thiol interacts with a non-sulfur precursor to yield a sulfide-containing compound. The non-sulfur precursor (in the gas or particle phase) may have contained $\mathrm{O}$ and $\mathrm{N}$ atoms, thus yielding a CHONS compound immediately after participating in one of the proposed reactions. Alternatively, the newly formed sulfide-containing compound may have undergone subsequent separate reactions with oxygen- and/or nitrogencontaining species (in the gas or particle phase) to form the observed sulfide-containing CHONS species. Here, we focused on possible reactions that could have contributed the sulfide group to these oxygen- and/or nitrogen-containing compounds (known emissions from forest fires, as discussed above). Earlier, we postulated that because most of the observed particle-phase CHONS compounds were SVOCs, these compounds were predominantly formed by reactions with more volatile gas-phase compounds. However, it is uncertain whether these sulfide-forming and CHONS-forming reactions all occurred in the gas phase with subsequent partitioning to the particle phase, heterogeneously, or in a combination of separate gas- and particle-phase chemistry. We suggest some possible sulfide-forming reactions here, yet we note that these proposed reactions are likely not comprehensive. Further work to elucidate the chemistry driving this sulfide and CHONS formation is needed.

Some possible reactions include (1) thiol-ene reactions, where a thiol reacts with an alkene (or alkyne), which can 
form carbon-sulfur bonds (Lowe, 2010). Alkenes are known to be prominent in emissions from boreal fires (Gilman et al., 2015; Hatch et al., 2015), and we observed similar structures in our gas-phase samples that likely included alkenes, cyclic alkanes, and/or monoterpenes (Fig. S13). (2) Thiol reactions with carbonyls, which can form hemithioacetals that subsequently dehydrate in the atmosphere to yield sulfides, are also possible (Jencks and Lienhard, 1966). This reaction is similar to the formation of enamines from carbonyls and dimethyl amine via the formation and subsequent dehydration of a carbinolamine, which has been shown to occur in ambient conditions (Duporté et al., 2016, 2017). (3) Thiol reactions with alcohols, which can form sulfides, are possible; these reaction rates are low in the absence of catalysts and require relatively high temperature to occur (i.e., 200-450 ${ }^{\circ} \mathrm{C}$ (Mashkina, 1991), temperatures that are relevant very close to the fire but unlikely in the cooled plume). (4) Another possibility is that a radical intermediate product formed during atmospheric oxidation of DMS (e.g., the methylthiomethyl radical $\left(\mathrm{CH}_{3} \mathrm{SCH}_{2}^{*}\right)$ from $\mathrm{OH}^{\bullet}$-driven hydrogen abstraction of DMS; Barnes et al., 2006) interacted with $\mathrm{CHN}$ and $\mathrm{CHON}$ precursors to yield the observed sulfide-containing CHONS products. However, the concentrations of the methylthiomethyl radical and similar radicals from other small sulfide precursors would likely be lower than those of other major drivers of in-plume radical chemistry (e.g., $\mathrm{O}_{2}, \mathrm{NO}_{x}$ ), thus making this reaction pathway less likely to contribute.

Based on our observations of these sulfide-containing products across flight screens, the overall timescale for these sulfide-forming reactions was likely approximately $1 \mathrm{~h}$ (or less). For the literature reactions referenced above, reaction timescales ranged from minutes to hours in laboratory experiments, but extrapolation to rates in an ambient wildfire plume is uncertain. Specifically, it is challenging to compare to predicted timescales for the proposed reactions without knowing the exact structure/identities of the reactants or the possible role of other key modifying factors in the plume (e.g., aerosol pH, presence of water).

\section{Implications and conclusions}

In this work, we performed the first high-resolution tandem mass spectrometry analysis of an evolving plume from a smoldering boreal forest fire. The results show clear evidence of gas-phase sulfur-containing emissions from the fire, and an increasing contribution from particle-phase CHONS compounds with sulfide functional groups as the plume evolved. Together, these results suggest the emission of gas-phase sulfur-containing compounds from the fire and subsequent gas- and/or particle-phase chemistry that produced multifunctional sulfide-containing CHONS compounds.

Sulfide functional groups in ambient air have been reported at a range of US locations from urban inland (1\%-
$7 \%$ sulfides), urban coastal ( $5 \%-12 \%$ sulfides), and remote forested ( $7 \%$ sulfides), and on average, sulfides comprised $28 \%$ of sulfur-containing functional groups at these sites (Ditto et al., 2020). However, in past work, $53 \%$ of these sulfides were present in CHOS compounds, while $34 \%$ were CHONS, and $13 \%$ were CHNS (in contrast to $21 \%, 71 \%$, and $8 \%$ in this study, respectively). Notably, at a northeastern US coastal site where there were several pollution events linked to long-distance transport of biomass burning smoke during field sampling (Rogers et al., 2020), 70\%-90\% of sulfides were present in CHONS compounds (Ditto et al., 2020), similar to the compound class distribution of sulfides discussed here (Fig. 3a).

These results, along with past observations, highlight that this type of chemistry and these types of reaction products may be relevant to other regions where concentrations of nitrogen and sulfur-containing precursors are high, such as in developing regions, emerging economies, or megacities where residential biomass burning is common and coincident with extensive use of sulfur-containing fossil fuels (e.g., coal). CHONS compounds have been reported in similar regions in past studies (Lin et al., 2012; Pan et al., 2013; Song et al., 2019; X. Wang et al., 2017, 2016; X. $\mathrm{K}$. Wang et al., 2017). Their formation is potentially important since the presence of sulfur, oxygen, and nitrogen atoms in organic compounds can affect particle phase state (e.g., solid, semi-solid, liquid), and mixing state (e.g., well-mixed, phase-separated) (DeRieux et al., 2018; Ditto et al., 2019; Van Krevelen and Te Nijenhuis, 2009). These physical properties may influence particles' chemical reactivity and overall persistence in the atmosphere, all of which contribute to the health and environmental impacts that communities and ecosystems experience from OA exposure. Future work to identify prominent functional groups in $\mathrm{CHONS}$ species in regions with high $\mathrm{CHONS}$ concentrations will help elucidate the formation chemistry of these functionalized compounds and understand and mitigate their associated impacts.

Code and data availability. Code and data are available upon request.

Author contributions. JCD ran samples, processed filter data, and compiled and interpreted results. $\mathrm{MH}$ processed adsorbent tube data. THM contributed to MS/MS analysis. SGM, KH, JL, and DRG collaborated on data interpretation. KH collected and processed AMS data. AL collected and processed PTR-ToF-MS data. SML designed the aircraft adsorbent tube collection system. PL and JJBW implemented the wing pod design. PL prepared the wing pods for collection and JJBW and JL collected the adsorbent tube samples. MJW and JL designed the filter collection system. MJW and $\mathrm{KH}$ collected filter samples. SML, KH, and JL designed the aircraft sampling study. JCD and DRG wrote the manuscript, with input from all co-authors. 
Competing interests. The authors declare that they have no conflict of interest.

Acknowledgements. The authors acknowledge GERSTEL for their collaboration with the TDU 3.5+ used to run the GC-APCI adsorbent tubes and filters discussed in this study. We thank the Environment and Climate Change Canada and National Research Council technical teams for their help in the construction and maintenance of cartridge sampling systems, specifically Tak Chan (Environment and Climate Change Canada) for help collecting samples. We also thank Jo Machesky (Yale) for help running adsorbent tube samples, Joe Lybik (Yale) for help packing adsorbent tubes, and Daniel Thompson (Natural Resources Canada) for informative discussion. The flights discussed in this study were embedded within an intensive 2018 oil sands monitoring campaign, and the oil sands monitoring program is acknowledged for enabling the flights.

Financial support. This research was supported by the National Science Foundation (grant no. AWD0001666) and Environment and Climate Change Canada.

Review statement. This paper was edited by James Allan and reviewed by two anonymous referees.

\section{References}

Aas, W., Mortier, A., Bowersox, V., Cherian, R., Faluvegi, G., Fagerli, H., Hand, J., Klimont, Z., Galy-Lacaux, C., Lehmann, C. M. B., Myhre, C. L., Myhre, G., Olivié, D., Sato, K., Quaas, J., Rao, P. S. P., Schulz, M., Shindell, D., Skeie, R. B., Stein, A., Takemura, T., Tsyro, S., Vet, R., and Xu, X.: Global and regional trends of atmospheric sulfur, Sci. Rep., 9, 1-11, https://doi.org/10.1038/s41598-018-37304-0, 2019.

Abatzoglou, J. T. and Williams, A. P.: Impact of anthropogenic climate change on wildfire across western US forests, P. Natl. Acad. Sci. USA, 113, 11770-11775, https://doi.org/10.1073/pnas.1607171113, 2016.

Ahern, A. T., Robinson, E. S., Tkacik, D. S., Saleh, R., Hatch, L. E., Barsanti, K. C., Stockwell, C. E., Yokelson, R. J., Presto, A. A., Robinson, A. L., Sullivan, R. C., and Donahue, N. M.: Production of Secondary Organic Aerosol During Aging of Biomass Burning Smoke From Fresh Fuels and Its Relationship to VOC Precursors, J. Geophys. Res.-Atmos., 124, 3583-3606, https://doi.org/10.1029/2018JD029068, 2019.

Akagi, S. K., Yokelson, R. J., Wiedinmyer, C., Alvarado, M. J., Reid, J. S., Karl, T., Crounse, J. D., and Wennberg, P. O.: Emission factors for open and domestic biomass burning for use in atmospheric models, Atmos. Chem. Phys., 11, 4039-4072, https://doi.org/10.5194/acp-11-4039-2011, 2011.

Andreae, M. O.: Emission of trace gases and aerosols from biomass burning - an updated assessment, Atmos. Chem. Phys., 19, 8523-8546, https://doi.org/10.5194/acp-19-8523-2019, 2019.

Canada's National Forest Inventory: Composition of Canada's Forests, available at: https://nfi.nfis.org/en, last access: 18 February 2020 .
Barbero, R., Abatzoglou, J. T., Larkin, N. K., Kolden, C. A., and Stocks, B.: Climate change presents increased potential for very large fires in the contiguous United States, Int. J. Wildl. Fire, 24, 892-899, https://doi.org/10.1071/WF15083, 2015.

Barnes, I., Hjorth, J., and Mihalapoulos, N.: Dimethyl sulfide and dimethyl sulfoxide and their oxidation in the atmosphere, Chem. Rev., 106, 940-975, https://doi.org/10.1021/cr020529+, 2006.

Bertrand, A., Stefenelli, G., Jen, C. N., Pieber, S. M., Bruns, E. A., Ni, H., Temime-Roussel, B., Slowik, J. G., Goldstein, A. H., El Haddad, I., Baltensperger, U., Prévôt, A. S. H., Wortham, H., and Marchand, N.: Evolution of the chemical fingerprint of biomass burning organic aerosol during aging, Atmos. Chem. Phys., 18, 7607-7624, https://doi.org/10.5194/acp-18-7607-2018, 2018.

Burgos, M. A., Mateos, D., Cachorro, V. E., Toledano, C., de Frutos, A. M., Calle, A., Herguedas, A., and Marcos, J. L.: An analysis of high fine aerosol loading episodes in north-central Spain in the summer 2013 - Impact of Canadian biomass burning episode and local emissions, Atmos. Environ., 184, 191-202, https://doi.org/10.1016/j.atmosenv.2018.04.024, 2018.

Buysse, C. E., Kaulfus, A., Nair, U., and Jaffe, D. A.: Relationships between Particulate Matter, Ozone, and Nitrogen Oxides during Urban Smoke Events in the Western US, Environ. Sci. Technol., 53, 12519-12528, https://doi.org/10.1021/acs.est.9b05241, 2019.

Colarco, P. R., Schoeberl, M. R., Doddridge, B. G., Marufu, L. T., Torres, O., and Welton, E. J.: Transport of smoke from Canadian forest fires to the surface near Washington, D.C.: Injection height, entrainment, and optical properties, J. Geophys. Res.-Atmos., 109, 1-12, https://doi.org/10.1029/2003JD004248, 2004.

Cottle, P., Strawbridge, K., and McKendry, I.: Long-range transport of Siberian wildfire smoke to British Columbia: Lidar observations and air quality impacts, Atmos. Environ., 90, 71-77, https://doi.org/10.1016/j.atmosenv.2014.03.005, 2014.

Davidian, J.-C. and Kopriva, S.: Regulation of Sulfate Uptake and Assimilation - the Same or Not the Same?, Mol. Plant, 3, 314325, https://doi.org/10.1093/MP/SSQ001, 2010.

DeRieux, W.-S. W., Li, Y., Lin, P., Laskin, J., Laskin, A., Bertram, A. K., Nizkorodov, S. A., and Shiraiwa, M.: Predicting the glass transition temperature and viscosity of secondary organic material using molecular composition, Atmos. Chem. Phys., 18, 6331-6351, https://doi.org/10.5194/acp-18-6331-2018, 2018.

Di Lorenzo, R. A., Place, B. K., VandenBoer, T. C., and Young, C. J.: Composition of Size-Resolved Aged Boreal Fire Aerosols: Brown Carbon, Biomass Burning Tracers, and Reduced Nitrogen, ACS Earth Sp. Chem., 2, 278-285, https://doi.org/10.1021/acsearthspacechem.7b00137, 2018.

Ditto, J. C., Barnes, E. B., Khare, P., Takeuchi, M., Joo, T., Bui, A. A. T., Lee-Taylor, J., Eris, G., Chen, Y., Aumont, B., Jimenez, J. L., Ng, N. L., Griffin, R. J., and Gentner, D. R.: An omnipresent diversity and variability in the chemical composition of atmospheric functionalized organic aerosol, Commun. Chem., 1, 75, https://doi.org/10.1038/s42004-018-0074-3, 2018.

Ditto, J. C., Joo, T., Khare, P., Sheu, R., Takeuchi, M., Chen, Y., Xu, W., Bui, A. A. T., Sun, Y., Ng, N. L., and Gentner, D. R.: Effects of Molecular-Level Compositional Variability in Organic Aerosol on Phase State and Thermodynamic Mixing Behavior, Environ. Sci. Technol., 53, 13009-13018, https://doi.org/10.1021/acs.est.9b02664, 2019. 
Ditto, J. C., Joo, T., Slade, J. H., Shepson, P. B., Ng, N. L., and Gentner, D. R.: Nontargeted Tandem Mass Spectrometry Analysis Reveals Diversity and Variability in Aerosol Functional Groups across Multiple Sites, Seasons, and Times of Day, Environ. Sci. Technol. Lett., 7, 60-69, https://doi.org/10.1021/acs.estlett.9b00702, 2020.

Donahue, N. M., Epstein, S. A., Pandis, S. N., and Robinson, A. L.: A two-dimensional volatility basis set: 1. organic-aerosol mixing thermodynamics, Atmos. Chem. Phys., 11, 3303-3318, https://doi.org/10.5194/acp-11-3303-2011, 2011.

Dreessen, J., Sullivan, J., and Delgado, R.: Observations and impacts of transported Canadian wildfire smoke on ozone and aerosol air quality in the Maryland region on June 9-12, 2015, J. Air Waste Ma., 66, 842-862, https://doi.org/10.1080/10962247.2016.1161674, 2016.

Duporté, G., Parshintsev, J., Barreira, L. M. F., Hartonen, K., Kulmala, M., and Riekkola, M. L.: NitrogenContaining Low Volatile Compounds from PinonaldehydeDimethylamine Reaction in the Atmosphere: A Laboratory and Field Study, Environ. Sci. Technol., 50, 4693-4700, https://doi.org/10.1021/acs.est.6b00270, 2016.

Duporté, G., Riva, M., Parshintsev, J., Heikkinen, E., Barreira, L. M. F., Myllys, N., Heikkinen, L., Hartonen, K., Kulmala, M., Ehn, M., and Riekkola, M. L.: Chemical Characterization of Gas- and Particle-Phase Products from the Ozonolysis of $\alpha$-Pinene in the Presence of Dimethylamine, Environ. Sci. Technol., 51, 56025610, https://doi.org/10.1021/acs.est.6b06231, 2017.

Fenn, M. E., Bytnerowicz, A., Schilling, S. L., and Ross, C. S.: Atmospheric deposition of nitrogen, sulfur and base cations in jack pine stands in the Athabasca Oil Sands Region, Alberta, Canada, Environ. Pollut., 196, 497-510, https://doi.org/10.1016/j.envpol.2014.08.023, 2015.

Forrister, H., Liu, J., Scheuer, E., Dibb, J., Ziemba, L., Thornhill, K. L., Anderson, B., Diskin, G., Perring, A. E., Schwarz, J. P., Campuzano-Jost, P., Day, D. A., Palm, B. P., Jimenez, J. L., Nenes, A. and Weber, R. J.: Evolution of brown carbon in wildfire plumes, Geophys. Res. Lett., 42, 4623-4630, 2015.

Forster, C., Wandinger, U., Wotawa, G., James, P., Mattis, I., Althausen, D., Simmonds, P., O'Doherty, S., Jennings, S. G., Kleefeld, C., Schneider, J., Trickl, T., Kreipl, S., Jäger, H. and Stohl, A.: Transport of boreal forest fire emissions from Canada to Europe, J. Geophys. Res.-Atmos., 106, 22887-22906, https://doi.org/10.1029/2001JD900115, 2001.

Gahan, J. and Schmalenberger, A.: The role of bacteria and mycorrhiza in plant sulfur supply, Front. Plant Sci., 5, 1-7, https://doi.org/10.3389/fpls.2014.00723, 2014.

Garofalo, L. A., Pothier, M. A., Levin, E. J. T., Campos, T., Kreidenweis, S. M., and Farmer, D. K.: Emission and Evolution of Submicron Organic Aerosol in Smoke from Wildfires in the Western United States, ACS Earth Sp. Chem., 3, 1237-1247, https://doi.org/10.1021/acsearthspacechem.9b00125, 2019.

Gilman, J. B., Lerner, B. M., Kuster, W. C., Goldan, P. D., Warneke, C., Veres, P. R., Roberts, J. M., de Gouw, J. A., Burling, I. R., and Yokelson, R. J.: Biomass burning emissions and potential air quality impacts of volatile organic compounds and other trace gases from fuels common in the US, Atmos. Chem. Phys., 15, 13915-13938, https://doi.org/10.5194/acp-15-139152015, 2015.
Hallquist, M., Wenger, J. C., Baltensperger, U., Rudich, Y., Simpson, D., Claeys, M., Dommen, J., Donahue, N. M., George, C., Goldstein, A. H., Hamilton, J. F., Herrmann, H., Hoffmann, T., Iinuma, Y., Jang, M., Jenkin, M. E., Jimenez, J. L., Kiendler-Scharr, A., Maenhaut, W., McFiggans, G., Mentel, Th. F., Monod, A., Prévôt, A. S. H., Seinfeld, J. H., Surratt, J. D., Szmigielski, R., and Wildt, J.: The formation, properties and impact of secondary organic aerosol: current and emerging issues, Atmos. Chem. Phys., 9, 5155-5236, https://doi.org/10.5194/acp9-5155-2009, 2009.

Hatch, L. E., Luo, W., Pankow, J. F., Yokelson, R. J., Stockwell, C. E., and Barsanti, K. C.: Identification and quantification of gaseous organic compounds emitted from biomass burning using two-dimensional gas chromatography-time-offlight mass spectrometry, Atmos. Chem. Phys., 15, 1865-1899, https://doi.org/10.5194/acp-15-1865-2015, 2015.

Hatch, L. E., Rivas-Ubach, A., Jen, C. N., Lipton, M., Goldstein, A. H., and Barsanti, K. C.: Measurements of I/SVOCs in biomass-burning smoke using solid-phase extraction disks and two-dimensional gas chromatography, Atmos. Chem. Phys., 18, 17801-17817, https://doi.org/10.5194/acp-18-17801-2018, 2018.

Hatch, L. E., Jen, C. N., Kreisberg, N. M., Selimovic, V., Yokelson, R. J., Stamatis, C., York, R. A., Foster, D., Stephens, S. L., Goldstein, A. H., and Barsanti, K. C.: Highly Speciated Measurements of Terpenoids Emitted from Laboratory and Mixed-Conifer Forest Prescribed Fires, Environ. Sci. Technol., 53, 9418-9428, https://doi.org/10.1021/acs.est.9b02612, 2019.

Hecobian, A., Liu, Z., Hennigan, C. J., Huey, L. G., Jimenez, J. L., Cubison, M. J., Vay, S., Diskin, G. S., Sachse, G. W., Wisthaler, A., Mikoviny, T., Weinheimer, A. J., Liao, J., Knapp, D. J., Wennberg, P. O., Kürten, A., Crounse, J. D., Clair, J. St., Wang, Y., and Weber, R. J.: Comparison of chemical characteristics of 495 biomass burning plumes intercepted by the NASA DC-8 aircraft during the ARCTAS/CARB-2008 field campaign, Atmos. Chem. Phys., 11, 13325-13337, https://doi.org/10.5194/acp-1113325-2011, 2011.

Hegg, D. A., Radke, L. F., Hobbs, P. V., and Brock, C. A.: Nitrogen and Sulfur Emissions From The Burning of Forest Products Near Large Urban Areas, J. Geophys. Res., 92, 701-714, 1987.

Hennigan, C. J., Miracolo, M. A., Engelhart, G. J., May, A. A., Presto, A. A., Lee, T., Sullivan, A. P., McMeeking, G. R., Coe, H., Wold, C. E., Hao, W.-M., Gilman, J. B., Kuster, W. C., de Gouw, J., Schichtel, B. A., Collett Jr., J. L., Kreidenweis, S. M., and Robinson, A. L.: Chemical and physical transformations of organic aerosol from the photo-oxidation of open biomass burning emissions in an environmental chamber, Atmos. Chem. Phys., 11, 7669-7686, https://doi.org/10.5194/acp11-7669-2011, 2011.

Huang, W. Z. and Schoenau, J. J.: Forms, amounts and distribution of carbon, nitrogen, phosphorus and sulfur in a boreal aspen forest soil, Can. J. Soil Sci., 76(3), 373-385, https://doi.org/10.4141/cjss96-045, 1996.

Iinuma, Y., Böge, O., and Herrmann, H.: Methyl-nitrocatechols: Atmospheric tracer compounds for biomass burning secondary organic aerosols, Environ. Sci. Technol., 44, 8453-8459, https://doi.org/10.1021/es102938a, 2010. 
Jencks, W. P. and Lienhard, G. E.: Thiol Addition to the Carbonyl Group. Equilibria and Kinetics, J. Am. Chem. Soc., 88, 39823995, https://doi.org/10.1021/ja00969a017, 1966.

Jiang, H., Frie, A. L., Lavi, A., Chen, J. Y., Zhang, H., Bahreini, R., and Lin, Y. H.: Brown Carbon Formation from Nighttime Chemistry of Unsaturated Heterocyclic Volatile Organic Compounds, Environ. Sci. Technol. Lett., 6, 184-190, https://doi.org/10.1021/acs.estlett.9b00017, 2019.

Jolly, W. M., Cochrane, M. A., Freeborn, P. H., Holden, Z. A., Brown, T. J., Williamson, G. J., and Bowman, D. M. J. S.: Climate-induced variations in global wildfire danger from 1979 to 2013, Nat. Commun., 6, 1-11, https://doi.org/10.1038/ncomms8537, 2015.

Khare, P., Marcotte, A., Sheu, R., Walsh, A. N., Ditto, J. C., and Gentner, D. R.: Advances in offline approaches for trace measurements of complex organic compound mixtures via soft ionization and high-resolution tandem mass spectrometry, J. Chromatogr. A, 1598, 163-174, https://doi.org/10.1016/j.chroma.2019.03.037, 2019.

Koss, A. R., Sekimoto, K., Gilman, J. B., Selimovic, V., Coggon, M. M., Zarzana, K. J., Yuan, B., Lerner, B. M., Brown, S. S., Jimenez, J. L., Krechmer, J., Roberts, J. M., Warneke, C., Yokelson, R. J., and de Gouw, J.: Non-methane organic gas emissions from biomass burning: identification, quantification, and emission factors from PTR-ToF during the FIREX 2016 laboratory experiment, Atmos. Chem. Phys., 18, 3299-3319, https://doi.org/10.5194/acp-18-3299-2018, 2018.

Landis, M. S., Edgerton, E. S., White, E. M., Wentworth, G. R., Sullivan, A. P., and Dillner, A. M.: The impact of the 2016 Fort McMurray Horse River Wildfire on ambient air pollution levels in the Athabasca Oil Sands Region, Alberta, Canada, Sci. Total Environ., 618, 1665-1676, https://doi.org/10.1016/j.scitotenv.2017.10.008, 2018.

Laskin, A., Smith, J. S., and Laskin, J.: Molecular Characterization of Nitrogen-Containing Organic Compounds in Biomass Burning Aerosols Using High-Resolution Mass Spectrometry, Environ. Sci. Technol., 43, 3764-3771, https://doi.org/10.1021/es803456n, 2009.

Leustek, T.: Sulfate Metabolism, Arab. B., 1, 1-16, https://doi.org/10.1199/tab.0017, 2002.

Li, S. M., Leithead, A., Moussa, S. G., Liggio, J., Moran, M. D., Wang, D., Hayden, K., Darlington, A., Gordon, M., Staebler, R., Makar, P. A., Stroud, C. A., McLaren, R., Liu, P. S. K., O’Brien, J., Mittermeier, R. L., Zhang, J., Marson, G., Cober, S. G., Wolde, M. and Wentzell, J. J. B.: Differences between measured and reported volatile organic compound emissions from oil sands facilities in Alberta, Canada, P. Natl. Acad. Sci. USA, 114, E3756E3765, https://doi.org/10.1073/pnas.1617862114, 2017.

Li, Y., Pöschl, U., and Shiraiwa, M.: Molecular corridors and parameterizations of volatility in the chemical evolution of organic aerosols, Atmos. Chem. Phys., 16, 3327-3344, https://doi.org/10.5194/acp-16-3327-2016, 2016.

Liggio, J., Li, S.-M., Hayden, K., Taha, Y. M., Stroud, C., Darlington, A., Drollette, B. D., Gordon, M., Lee, P., Liu, P., Leithead, A., Moussa, S. G., Wang, D., OBrien, J., Mittermeier, R. L., Brook, J. R., Lu, G., Staebler, R. M., Han, Y., Tokarek, T. W., Osthoff, H. D., Makar, P. A., Zhang, J., Plata, D. L., and Gentner, D. R.: Oil sands operations as a large source of secondary organic aerosols, Nature, 534, 91-94, https://doi.org/10.1038/nature17646, 2016.

Liggio, J., Moussa, S. G., Wentzell, J., Darlington, A., Liu, P., Leithead, A., Hayden, K., O'Brien, J., Mittermeier, R. L., Staebler, R., Wolde, M., and Li, S.-M.: Understanding the primary emissions and secondary formation of gaseous organic acids in the oil sands region of Alberta, Canada, Atmos. Chem. Phys., 17, 8411-8427, https://doi.org/10.5194/acp-17-8411-2017, 2017.

Lim, C. Y., Hagan, D. H., Coggon, M. M., Koss, A. R., Sekimoto, K., de Gouw, J., Warneke, C., Cappa, C. D., and Kroll, J. H.: Secondary organic aerosol formation from the laboratory oxidation of biomass burning emissions, Atmos. Chem. Phys., 19, 1279712809, https://doi.org/10.5194/acp-19-12797-2019, 2019.

Lin, P., Yu, J. Z., Engling, G., and Kalberer, M.: Organosulfates in humic-like substance fraction isolated from aerosols at seven locations in East Asia: A study by ultra-high-resolution mass spectrometry, Environ. Sci. Technol., 46, 13118-13127, https://doi.org/10.1021/es303570v, 2012.

Lin, P., Fleming, L. T., Nizkorodov, S. A., Laskin, J., and Laskin, A.: Comprehensive Molecular Characterization of Atmospheric Brown Carbon by High Resolution Mass Spectrometry with Electrospray and Atmospheric Pressure Photoionization, Anal. Chem., 90, 12493-12502, https://doi.org/10.1021/acs.analchem.8b02177, 2018.

Liu, J. C., Wilson, A., Mickley, L. J., Dominici, F., Ebisu, K., Wang, Y., Sulprizio, M. P., Peng, R. D., Yue, X., Son, J.-Y., Anderson, G. B., and Bell, M. L.: Wildfirespecific Fine Particulate Matter and Risk of Hospital Admissions in Urban and Rural Counties, Epidemiology, 28, 77-85, https://doi.org/10.1097/EDE.0000000000000556, 2017.

Liu, Y., Liggio, J., Staebler, R., and Li, S.-M.: Reactive uptake of ammonia to secondary organic aerosols: kinetics of organonitrogen formation, Atmos. Chem. Phys., 15, 1356913584, https://doi.org/10.5194/acp-15-13569-2015, 2015.

Lowe, A. B.: Thiol-ene "click" reactions and recent applications in polymer and materials synthesis, Polym. Chem., 1, 17-36, https://doi.org/10.1039/b9py00216b, 2010.

Makar, P. A., Akingunola, A., Aherne, J., Cole, A. S., Aklilu, Y.A., Zhang, J., Wong, I., Hayden, K., Li, S.-M., Kirk, J., Scott, K., Moran, M. D., Robichaud, A., Cathcart, H., Baratzedah, P., Pabla, B., Cheung, P., Zheng, Q., and Jeffries, D. S.: Estimates of exceedances of critical loads for acidifying deposition in Alberta and Saskatchewan, Atmos. Chem. Phys., 18, 9897-9927, https://doi.org/10.5194/acp-18-9897-2018, 2018.

Mashkina, A. V.: Catalytic Synthesis Of Sulfides Sulfoxides and Sulfones, Sulfur reports, 10, 279-388, https://doi.org/10.1080/01961779108048759, 1991.

McLinden, C. A., Fioletov, V., Krotkov, N. A., Li, C., Boersma, K. F., and Adams, C.: A Decade of Change in $\mathrm{NO}_{2}$ and $\mathrm{SO}_{2}$ over the Canadian Oil Sands As Seen from Space, Environ. Sci. Technol., 50, 331-337, https://doi.org/10.1021/acs.est.5b04985, 2016.

Meng, F. R., Bourque, C. P. A., Belczewski, R. F., Whitney, N. J., and Arp, P. A.: Foliage responses of spruce trees to long-term low-grade sulfur dioxide deposition, Environ. Pollut., 90, 143152, https://doi.org/10.1016/0269-7491(94)00101-I, 1995.

Murphy, B. N., Donahue, N. M., Robinson, A. L., and Pandis, S. N.: A naming convention for atmospheric organic aerosol, Atmos. Chem. Phys., 14, 5825-5839, https://doi.org/10.5194/acp14-5825-2014, 2014. 
Nozière, B., Kalberer, M., Claeys, M., Allan, J., D’Anna, B., Decesari, S., Finessi, E., Glasius, M., Grgić, I., Hamilton, J. F., Hoffmann, T., Iinuma, Y., Jaoui, M., Kahnt, A., Kampf, C. J., Kourtchev, I., Maenhaut, W., Marsden, N., Saarikoski, S., Schnelle-Kreis, J., Surratt, J. D., Szidat, S., Szmigielski, R., and Wisthaler, A.: The Molecular Identification of Organic Compounds in the Atmosphere: State of the Art and Challenges, Chem. Rev., 115, 3919-3983, https://doi.org/10.1021/cr5003485, 2015.

Nyborg, M., Solberg, E. D., Malhi, S. S., Takyi, S., Yeung, P., and Chaudhry, M.: Deposition of anthropogenic sulphur dioxide on soils and resulting soil acidification, Dev. Plant. Soil Sci., 147156, https://doi.org/10.1007/978-94-011-3438-5_16, 1991.

Onda, Y.: Oxidative protein-folding systems in plant cells, Int. J. Cell Biol., 2013, 585431, https://doi.org/10.1155/2013/585431, 2013.

Pan, Y. P., Wang, Y. S., Tang, G. Q., and Wu, D.: Spatial distribution and temporal variations of atmospheric sulfur deposition in Northern China: insights into the potential acidification risks, Atmos. Chem. Phys., 13, 1675-1688, https://doi.org/10.5194/acp13-1675-2013, 2013.

Reid, C. E., Brauer, M., Johnston, F. H., Jerrett, M., Balmes, J. R., and Elliott, C. T.: Critical review of health impacts of wildfire smoke exposure, Environ. Health Persp., 124, 1334-1343, https://doi.org/10.1289/ehp.1409277, 2016.

Rogers, H. M., Ditto, J. C., and Gentner, D. R.: Evidence for impacts on surface-level air quality in the northeastern US from long-distance transport of smoke from North American fires during the Long Island Sound Tropospheric Ozone Study (LISTOS) 2018, Atmos. Chem. Phys., 20, 671-682, https://doi.org/10.5194/acp-20-671-2020, 2020.

Sekimoto, K., Koss, A. R., Gilman, J. B., Selimovic, V., Coggon, M. M., Zarzana, K. J., Yuan, B., Lerner, B. M., Brown, S. S., Warneke, C., Yokelson, R. J., Roberts, J. M., and de Gouw, J.: High- and low-temperature pyrolysis profiles describe volatile organic compound emissions from western US wildfire fuels, Atmos. Chem. Phys., 18, 9263-9281, https://doi.org/10.5194/acp18-9263-2018, 2018.

Sengupta, D., Samburova, V., Bhattarai, C., Kirillova, E., Mazzoleni, L., Iaukea-Lum, M., Watts, A., Moosmüller, H., and Khlystov, A.: Light absorption by polar and non-polar aerosol compounds from laboratory biomass combustion, Atmos. Chem. Phys., 18, 10849-10867, https://doi.org/10.5194/acp-18-108492018, 2018..

Sheu, R., Marcotte, A., Khare, P., Charan, S., Ditto, J. C., and Gentner, D. R.: Advances in offline approaches for chemically speciated measurements of trace gas-phase organic compounds via adsorbent tubes in an integrated sampling-to-analysis system, J. Chromatogr. A, 1575, 80-90, https://doi.org/10.1016/j.chroma.2018.09.014, 2018.

Song, J., Li, M., Fan, X., Zou, C., Zhu, M., Jiang, B., Yu, Z., Jia, W., Liao, Y., and Peng, P.: Molecular Characterization of WaterAnd Methanol-Soluble Organic Compounds Emitted from Residential Coal Combustion Using Ultrahigh-Resolution Electrospray Ionization Fourier Transform Ion Cyclotron Resonance Mass Spectrometry, Environ. Sci. Technol., 53, 13607-13617, https://doi.org/10.1021/acs.est.9b04331, 2019.
Updyke, K. M., Nguyen, T. B., and Nizkorodov, S. A.: Formation of brown carbon via reactions of ammonia with secondary organic aerosols from biogenic and anthropogenic precursors, Atmos. Environ., 63, 22-31, https://doi.org/10.1016/j.atmosenv.2012.09.012, 2012.

Val Martín, M., Honrath, R. E., Owen, R. C., Pfister, G., Fialho, P., and Barata, F.: Significant enhancements of nitrogen oxides, black carbon, and ozone in the North Atlantic lower free troposphere resulting from North American boreal wildfires, J. Geophys. Res.-Atmos., 111, 1-17, https://doi.org/10.1029/2006JD007530, 2006.

Van Krevelen, D. W. and Te Nijenhuis, K.: Properties of Polymers, 4th ed., Elsevier, Amsterdam, 2009.

Vicente, A., Alves, C., Calvo, A. I., Fernandes, A. P., Nunes, T., Monteiro, C., Almeida, S. M., and Pio, C.: Emission factors and detailed chemical composition of smoke particles from the 2010 wildfire season, Atmos. Environ., 71, 295-303, https://doi.org/10.1016/j.atmosenv.2013.01.062, 2013.

Wang, X., Wang, H., Jing, H., Wang, W. N., Cui, W., Williams, B. J., and Biswas, P.: Formation of NitrogenContaining Organic Aerosol during Combustion of HighSulfur-Content Coal, Energy and Fuels, 31, 14161-14168, https://doi.org/10.1021/acs.energyfuels.7b02273, 2017a.

Wang, X. K., Rossignol, S., Ma, Y., Yao, L., Wang, M. Y., Chen, J. M., George, C., and Wang, L.: Molecular characterization of atmospheric particulate organosulfates in three megacities at the middle and lower reaches of the Yangtze River, Atmos. Chem. Phys., 16, 2285-2298, https://doi.org/10.5194/acp16-2285-2016, 2016

Wang, X. K., Hayeck, N., Brüggemann, M., Yao, L., Chen, H., Zhang, C., Emmelin, C., Chen, J., George, C., and Wang, L.: Chemical Characteristics of Organic Aerosols in Shanghai: A Study by Ultrahigh-Performance Liquid Chromatography Coupled With Orbitrap Mass Spectrometry, J. Geophys. Res.-Atmos., 122, 11703-11722, https://doi.org/10.1002/2017JD026930, 2017b.

Ward, D. E.: Factors Influencing the Emissions of Gases and Particulate Matter from Biomass Burning, in: Fire in the Tropical Biota: Ecosystem Processes and Global Challenges, edited by: Goldammer, J. G., Springer-Verlag Berlin Heidelberg, 84, 418436, https://doi.org/10.1007/978-3-642-75395-4, 1990.

Wong, J. P. S., Tsagkaraki, M., Tsiodra, I., Mihalopoulos, N., Violaki, K., Kanakidou, M., Sciare, J., Nenes, A., and Weber, R. J.: Effects of Atmospheric Processing on the Oxidative Potential of Biomass Burning Organic Aerosols, Environ. Sci. Technol., 53, 6747-6756, https://doi.org/10.1021/acs.est.9b01034, 2019.

Yokelson, R. J., Burling, I. R., Gilman, J. B., Warneke, C., Stockwell, C. E., de Gouw, J., Akagi, S. K., Urbanski, S. P., Veres, P., Roberts, J. M., Kuster, W. C., Reardon, J., Griffith, D. W. T., Johnson, T. J., Hosseini, S., Miller, J. W., Cocker III, D. R., Jung, H., and Weise, D. R.: Coupling field and laboratory measurements to estimate the emission factors of identified and unidentified trace gases for prescribed fires, Atmos. Chem. Phys., 13, 89-116, https://doi.org/10.5194/acp-13-89-2013, 2013. 